\title{
¿Un elefante más?
}

Keywords: elefantes; safaris; cacerías

Hace unos meses, el periódico francés "Le Monde" (Le Monde", 31 de Diciembre de 2011), llamaba la atención sobre la masacre de elefantes en África. En cifras que pueden contrastarse, se sabe que, el pasado año 2011, se han recolectado y han sido objeto de venta 23 toneladas de marfil, lo que, según la organización Traffic, equivale a unos 2.500 elefantes. Afirmar que la situación del elefante africano se agrava, no es más que una reiteración.

Quien ha perpetrado tales matanzas, que continúan a buen ritmo en el presente año, son, en muchas ocasiones, mercenarios contratados para hacerse con los colmillos, cuya demanda ha ascendido de forma vertiginosa en Asia y, más concretamente en Malasia. Como consecuencia, desde mediados de enero a mediados de febrero de este año, se han exterminado 200 elefantes en el norte de Camerún, con toda impunidad y con la más absoluta indiferencia por parte de las autoridades del país. En otras ocasiones, la muerte de elefantes, búfalos, rinocerontes, u otras especies igualmente valiosas, se lleva a cabo en safaris organizados en África, o en partidas de caza de osos que aún consienten países europeos como Hungría, Rumanía o Polonia, dejando en el olvido la rigurosa legislación de la UE sobre la caza y las limitaciones de la misma. Todo se justifica, al parecer, por un pasatiempo elitista.

Ciertamente, hay países del cono sur de África -como es el caso de Bostwana-, que consienten la caza de elefantes y otras especies salvajes, en recintos paradisíacos, con la justificación de que tal actividad es una fuente de ingresos fundamental para el país, pues genera una gran cantidad de puestos de trabajo. Y, añado yo, de comercio ilegal, para lo que el convenio CITES, resulta una metáfora.

"Matar un elefante es peor que un delito... Es un pecado, el único que se puede cometer pagando una licencia", a muchos cinéfilos, que seguimos la trayectoria como director de Clint Eastwood, no se nos han olvidado las palabras con las que el cazador renuncia a abatir de un tiro a un elefante que, por fín, se pone en su punto de mira. Es el final de una película ("Cazador blanco, corazón negro"), que es todo un homenaje a la filmografía de John Huston y un homenaje también a una criatura noble, inteligente y sensible como el elefante. Un verdadero milagro de la naturaleza. Un esplendor de vida en libertad. No sé qué justificación pueda tener y cómo se explica que matar a tal criatura, a cualquier ejemplar de la fauna salvaje, pueda constituir una diversión, o una actividad de ocio legitimada por una pretendida contribución a la conservación del equilibrio de la naturaleza.

Hay algo de obsceno en cazar por pasatiempo. Hay algo de ridículo y de cruel en fotografiarse con el cadáver de tu víctima. Extender a los animales el respeto que merecen, extender el llamado "círculo de la compasiónl", no hace más que ennoblecer a los seres humanos. No está muy lejos el tiempo en el que cazar elefantes o cualquier animal salvaje, provocará rechazo, cada vez mayor, en capas cada vez mas extensas de la población.

Se prohibió la caza del zorro en Gran Bretaña -y no fue sencillo pues se trataba de un pasatiempo ligado a la vida rural y practicado por la nobleza rural-. No se ha hundido el equilibrio ecológico, no se ha hundido la economía británica, no parecen haberse quebrado las tradiciones ni haber sufrido un colapso la identidad de los ingleses. Es frecuente que la Reina Isabel II, que celebra sus 60 años de entronización, aparezca con sus perros, con sus caballos, con una imagen que corresponde a aquello que, en los países anglosajones, se considera un rasgo admirable de la personalidad, que es amar a los animales y mostrar compasión por ellos, también públicamente. Es frecuente también ver a los presidentes americanos con 
sus animales de compañía (hasta conocemos sus nombres...). Que sea una imagen difundida con fines de propaganda quizá no se pueda negar, pero es una propaganda que difunde los valores de una sociedad en su conjunto.

No quisiera (no quisiéramos muchos) volver a ver a ningún representante político de España posando con un cadáver y un rifle de caza. Preferiría que ningún elefante más se exhibiera, muerto sin piedad, junto a alguien que -se supone- nos representa como ciudadanos civilizados. Preferiría que apareciera paseando a su perro (como, por cierto, vimos hacer el año pasado al actual Ministro de Justicia), o que, en la web de la Moncloa o de la Zarzuela, empezaran también a aparecer las fotos de los animales de compañía que allí viven, si es que los hay!. Algo estaría empezando a cambiar.

LA EDITORA

Teresa Giménez-Candela Catedrática de Derecho Romano Animal Law Profesor Universitat Autònoma de Barcelona 